\title{
Impact of temporary desiccation on the mobility of nutrients and metals from sediments of Loskop Reservoir, Olifants River
}

\author{
J Dabrowski*, DS Baldwin ${ }^{3}$, JM Dabrowski ${ }^{2}$, L Hill² and J Shadung ${ }^{2}$ \\ 'Sustainability Research Unit, Nelson Mandela Metropolitan University, 1 Madiba Drive, Private Bag X6531, George 6530, South Africa \\ ${ }^{2}$ Council for Scientific and Industrial Research (CSIR), Natural Resources \& the Environment, P.O. Box 395, Pretoria 0001, South Africa \\ ${ }^{3}$ CSIRO and the Murray-Darling Freshwater Research Centre, La Trobe University, P.O. Box 821 Wodonga, Victoria, Australia
}

\begin{abstract}
South Africa is prone to droughts and is heavily dependent on stored water resources. Few studies in South Africa have investigated the impact of drought on water quality when rainfall resumes and reservoir sediments are rewet. Other research has shown that several negative impacts may occur with rewetting, including eutrophication, and acidification with increased metal solubility. In this study, the impact of drying and rewetting sediments on the mobility of nutrients and metals is explored using sediments from Loskop Reservoir. Rarely exposed sediments were collected from three sites, dried at $35^{\circ} \mathrm{C}$ for 36 days, and then rewet under aerobic conditions. Filtered water samples were collected on Days $1,2,4$,

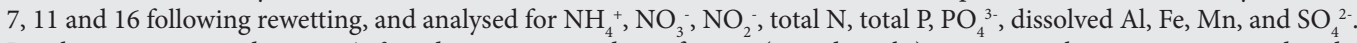
Results were expressed as mass $/ \mathrm{m}^{2}$, and were compared to reference (non-drought) treatments that were maintained under saturated conditions. Acute toxicity tests were performed using Daphnia magna to establish if toxic effects were associated with changes in water quality following sediment rewetting. Following rewetting, elevated $\mathrm{SO}_{4}^{2-}$ indicated the mobilisation of acid from sulfide oxidation, with an associated reduction in $\mathrm{pH}$. Nitrification was evident as high quantities of organic $\mathrm{N}$ and $\mathrm{NH}_{4}^{+}$were initially released, followed by increases in $\mathrm{NO}_{2}^{-}+\mathrm{NO}_{3}$. Total $\mathrm{P}$ increased, but $\mathrm{PO}_{4}{ }^{3-}$ reduced. This was attributed to complexes formed between $\mathrm{PO}_{4}{ }^{3-}$ and $\mathrm{Fe}\left(\mathrm{FePO}_{4}\right)$ and $\mathrm{Al}\left(\mathrm{AlPO}_{4}\right)$. Amounts of $\mathrm{Fe}$ and $\mathrm{Al}$ released were lower following rewetting due to the formation of relatively immobile (hydr)oxides. In contrast, $\mathrm{Mn}$ increased substantially reaching maximum values $>2300 \mathrm{mg} / \mathrm{m}^{2}(14000 \mu \mathrm{g} / \mathrm{L})$. There were no acute toxic effects observed to D. magna. This study highlights the potential for acidification, mobilisation of nutrients, $\mathrm{SO}_{4}^{2-}$, and $\mathrm{Mn}$ following rewetting of reservoir sediments under aerobic conditions. This information may be incorporated into reservoir and catchment management plans in the form of revised water quality guidelines and a better ability to predict how drought impacts water quality in our stored water resources.
\end{abstract}

Keywords: sediment, drought, drying, rewetting, nutrient and metal release, Loskop Reservoir

\section{INTRODUCTION}

South Africa is prone to periods of drought and is heavily dependent on stored water resources. Evidence from observed rainfall trends (Kruger, 2006) and model projections of climate change indicate that southern Africa may become hotter and drier, with a higher incidence of extreme events like heat-wave days and droughts in the future (Engelbrecht et al., 2009, 2015). This will place increasing pressure on stored water resources. When droughts occur, the most obvious impact is reduced water quantity. However, few studies in South Africa have investigated the impact of drought on water quality when rainfall resumes and desiccated sediments are rewet. In reservoirs, large areas of previously submerged sediment can be exposed for extended periods during drought until normal rainfall resumes. Under these circumstances sediment is exposed to air and desiccation, which affects nutrient dynamics (Birch, 1960; Qiu and McComb, 1995), microbial communities (Rees et al., 2006), and the oxidative state of elements. Rewetting of sediments can result in acidification and eutrophication, and disrupts nutrient cycling and microbial processes (Lake, 2011). Reservoirs that serve as a repository for pollutants from various land uses in the catchment may be particularly susceptible to water quality impacts following drought. This can impact negatively on ecosystem health and

\footnotetext{
* To whom all correspondence should be addressed.

甶083 256 3159; e-mail: jackie@confluent.co.za

Received 7 December 2015; accepted in revised form 14 November 2016
}

carry significant cost implications as water may require additional treatment for various beneficial uses.

Declining environmental quality in the Olifants River, South Africa, has emphasised the need to better understand how aquatic ecosystems respond to drought. A severe drought between 2002 and 2005 resulted in drastically reduced water levels at Loskop Reservoir (LR; $<25 \%$ full) in the upper catchment of the Olifants River. Large areas of sediment in the reservoir were exposed to desiccation during the drought, and at the lowest water levels in early 2004 the reservoir was drawn down by $15 \mathrm{~m}$ (Dabrowski et al., 2013). Although water levels have reduced to this level and lower during previous droughts, these events are infrequent, and water level draw-down is not a standard management practice applied at LR. Once normal rainfall resumed and the reservoir re-filled in 2006, several changes in the structure and function of the aquatic ecosystem were observed in the following years. Along with increased concentrations of $\mathrm{N}$ and $\mathrm{P}$, blooms of Microcystis aeruginosa in summer and Ceratium hirundinella in winter became frequent. During 2009, reduced $\mathrm{pH}$ levels ranging from 5.9 to 6.8 were recorded near the inflow (Oberholster et al., 2010). Several large fish kills of various species (> 11 tons) occurred between 2006 and 2007, and both Nile crocodiles (Crocodylus niloticus) and Mozambique tilapia (Oreochromis mossambicus) were diagnosed with pansteatitis (yellow fat disease; Dabrowski et al., 2013). Pansteatitis was responsible for $>180$ crocodile deaths at around the same time downstream on the Olifants River in the Kruger National Park (KNP), South Africa's premier nature conservation 
area and a major tourist attraction. This area also experienced very low water levels due to the drought during the same time period. Despite significant efforts to determine the cause of pansteatitis at both locations, the ultimate cause remains elusive. Potential causes that have been explored include opportunistic piscivory following fish kills (Dabrowski et al., 2014a); bioaccumulation of $\mathrm{Al}$ and $\mathrm{Fe}$ in the food chain (Oberholster et al., 2012); and altered aquatic food-webs (Huchzermeyer et al., 2011). Outbreaks of pansteatitis in aquatic fauna concurrent to blooms of $M$. aeruginos a have been previously documented (Nichols et al., 1986; Neagari et al., 2011); however, no definitive link between the disease and cyanobacteria has been established. Although the simultaneous timing of the outbreaks at two isolated locations on the Olifants River may have been coincidental, it is possible the drought may have somehow been related as a common environmental factor affecting both locations. Apart from the effects on aquatic ecosystem health, the drought had significant implications for other water users. LR supplies water to the second largest irrigation board in South Africa. Following the drought, deteriorating water quality from the reservoir resulted in blooms of filamentous algae like Cladophora glomerata in irrigation canals, requiring costly treatment with algaecides and maintenance of infrastructure (Oberholster and Botha, 2011).

The most significant land-uses affecting water quality in the catchment of LR are extensive coal-mining and the discharge of inadequately treated nutrient-rich effluent from wastewater treatment works (Dabrowski and De Klerk, 2013). The influence of current and especially abandoned coal mines is reflected by steadily increasing sulfate $\left(\mathrm{SO}_{4}^{2-}\right)$ concentrations, and periodically elevated concentrations of $\mathrm{Al}, \mathrm{Fe}$ and $\mathrm{Mn}$ (Oberholster et al., 2010; Dabrowski et al., 2013). Both total phosphorus (TP) and orthophosphate $\left(\mathrm{PO}_{4}^{3-}\right)$ have shown increasing trends in $\mathrm{LR}$, with a distinct peak in TP when the reservoir refilled after the drought (Dabrowski et al., 2013). Sediments in LR no doubt act as a sink for various pollutants entering the system, as improvements in the water quality are clearly evident $<100 \mathrm{~km}$ downstream in Flag Boshielo Reservoir (Dabrowski et al., 2014b). On the basis of research conducted in other regions, it is conceivable that several of the impacts observed in LR may have been related to drying (during drought) and rewetting (following drought) pollutant-enriched sediments.

The build-up of sulfur in sediments can lead to a number of adverse environmental outcomes when sediments are rewet following drought. Under saturated conditions in the anaerobic zone of the sediment, sulfate-reducing bacteria use sulfate as the terminal electron acceptor during anaerobic respiration, with hydrogen sulfide $\left(\mathrm{H}_{2} \mathrm{~S}\right)$ as the respiratory end product. Sulfide reacts with various metals including Fe to form mineral sulfides such as pyrite. Oxidation of sulfidic sediments (containing pyrite) during drought can cause acidification, deoxygenation, and mobilization of metals when sediments are rewet (Baldwin and Fraser, 2009). The potential for acid production during pyrite oxidation may be reduced in systems that are wellbuffered (Lucassen et al., 2002). The release of nutrients following rewetting can result from physico-chemical and biological processes. Large pulses of $\mathrm{N}$ and $\mathrm{P}$ release have been reported due to drying-induced microbial-cell lysis, breakdown of organic material, and drying-induced decrease in P sorption (Qiu and McComb, 1994; Qiu and McComb, 1995; Keitel et al., 2016). The flush in nutrients may alter the N/P ratio in lakes, thus affecting phytoplankton species abundance and diversity (Lake, 2011). The release of $\mathrm{P}$ following rewetting of sediments may be exacerbated under repeated wetting and drying cycles (Schonbrunner et al., 2012). The post-drought phytoplankton response depends strongly on the pre-drought trophic state. In even a mildly eutrophic lake (such as LR), drought can push the phytoplankton assemblage from mixed diversity to one dominated by potentially toxic cyanobacteria (Naselli-Flores, 2003; Baldwin et al., 2006; Lake, 2011).

Given the complex combination of nutrient-rich effluent and diluted acid mine drainage entering the reservoir, sediments in $\mathrm{LR}$ are likely to be enriched in nutrients, metals and $\mathrm{SO}_{4}^{2-}$. The aim of this study was to determine how drying and rewetting LR sediments would influence the overlying water quality, with an emphasis on the mobilisation of nutrients and metals that are known to originate from the catchment. Fish kills and die-offs of other aquatic biota unrelated to pansteatitis, following the drought, provided motivation to examine the relative acute toxicity of the overlying water to a single organism, the cladoceran Daphnia magna. Daphnia were chosen as test organism because in aquatic ecosystems they are known to feed on particles in both the water column and sediment, and are as a result exposed to both water-soluble and particle-bound contaminants (Soucek et al., 2000). The tests were used for screening purposes to establish whether any toxic effects could be associated with changes in water quality following rewetting of dried sediments. This study can provide valuable insights for reservoirs elsewhere that are affected by a similar combination of impacts.

\section{METHODS}

\section{Study site}

The Olifants River is the main inflow to LR. Prior research at LR divided the reservoir into 3 zones following a flow gradient that is highest at the inflow (riverine zone) and decreases through the transitional zone to the lacustrine zone (Fig. 1; Dabrowski et al., 2013). Sampling was conducted at 3 sites. Sites 1 and 2 were in the transitional zone and Site 3 was in the lacustrine zone. Dense growth of recently-established water hyacinth (Eichhornia crassipes) prevented access to previously monitored sampling sites towards the inflow in the transitional and riverine zones. This was unfortunate as previous research has shown that the transitional zone upstream of Site 1 is a 'hot-spot' for fish kills, low-oxygen events, and algal blooms (Dabrowski et al., 2013). However, algal blooms and fish kills have been previously observed at each of the three identified sites.

\section{Sediment collection}

Sediment samples were collected during winter when the water column was isothermal, and the top layer of sediment was under aerobic conditions. Samples of approximately the top $5 \mathrm{~cm}$ were collected using an Ekman grab sampler. Five replicate samples were collected from each of the three sites. Replicate samples were collected from the same depth within each zone, at least $5 \mathrm{~m}$ apart. Depths at all sites ranged from 8 to $12 \mathrm{~m}$ representing sediment that is rarely exposed to desiccation except in extreme drawdown events. Samples were stored in plastic bags and kept on ice while transported to the laboratory. At the laboratory, replicates were pooled, homogenised and then re-divided to ensure consistency.

\section{Sediment characterisation}

A sub-sample was collected from three of the sediment samples collected at each site. These samples were used to characterise 
the sediment and were analysed for loss on ignition (organic matter), particle size, $\mathrm{Al}, \mathrm{Fe}, \mathrm{Mn}$ and total S. Sediments were freeze-dried and then ball milled. Metals in the sediment were analysed by microwave digestion using nitric acid $\left(\mathrm{HNO}_{3}\right)$, perchloric acid $\left(\mathrm{HClO}_{3}\right)$ and hydrogen peroxide $\left(\mathrm{H}_{2} \mathrm{O}_{2}\right)(\mathrm{CSIR}$ Method MALS 4.5). Gravel (> $2 \mathrm{~mm})$, sand $(63 \mu \mathrm{m}-2000 \mu \mathrm{m})$ and mud $(<63 \mu \mathrm{m})$ were analysed using gravimetric methods. Sediment samples were sieved to separate fractions then ovendried $\left(105^{\circ} \mathrm{C}\right)$ and weighed.

\section{Microcosm experiment}

A microcosm experiment was conducted to determine the effects of sediment drying and re-wetting on water quality under aerobic conditions. Approximately $600 \mathrm{~g}$ of sediment was transferred into individual $3 \mathrm{~L}$ glass containers. All glassware was pre-washed using phosphate-free soap, and then soaked for $24 \mathrm{~h}$ in $2 \% \mathrm{HCl}$ before being rinsed with distilled water and dried. Containers were covered with foil and kept in the dark to inhibit photosynthesis. Control containers (five from each site) were immediately filled with $2 \mathrm{~L}$ artificial lake water, kept aerated, and remained inundated for the duration of the study. Artificial lake water was made up from Milli-Q water with a $\mathrm{pH}$ of 6.6 adjusted to the average conductivity of Loskop Dam, $400 \mu \mathrm{S} \mathrm{cm}^{-1}$, using $\mathrm{NaCl}$. To simulate desiccation during drought, experimental containers (five from each site) were incubated at $35^{\circ} \mathrm{C}$ for 36 days and weighed until reaching a constant weight indicating no further moisture loss. Pre- and post-drying weights were measured as an estimate of the sediment moisture content. Containers were then filled with artificial lake water and maintained under aerated conditions using airstones. Six measurements $(200 \mathrm{~mL}$ each) of water quality were taken on Days 1, 2, 4, 7, 11 and 16, from both control and experimental containers. Day 1 samples were collected within $3 \mathrm{~h}$ of establishment of experimental treatments. All analyses were performed by the analytical laboratory at the Council for Scientific and Industrial Research (CSIR). Water samples were filtered through $0.45 \mu \mathrm{m}$ pore size Whatman filters prior to being analysed for dissolved nutrients, metals and sulfate using standard methods (APHA, 2005). Following filtration, samples were acidified using $\mathrm{HNO}_{3}$ which dissociates any smaller colloidal or complexed molecules into their ionic and elemental state. Water quality parameters measured were ammonium $\left(\mathrm{NH}_{4}^{+}\right)$, nitrate plus nitrite $\left(\mathrm{NO}_{3}^{-}+\mathrm{NO}_{2}^{-}\right)$total nitrogen (TN), TP, $\mathrm{PO}_{4}^{3-}$, dissolved $\mathrm{Al}, \mathrm{Fe}, \mathrm{Mn}$, and $\mathrm{SO}_{4}^{2-}$. The total quantity of each parameter released from the sediments (mass $/ \mathrm{m}^{2}$ ) was estimated from the concentration $(\mathrm{mg} / \mathrm{L})$ in the overlying water and corrected for the amount removed during previous sample collections.

\section{Toxicity test}

Acute toxicity tests were performed using D. magna according to the USEPA (2002) method. The approach followed with the microcosm experiment was repeated with the toxicity testing, using $50 \mathrm{~mL}$ glass beakers. For each of the five replicates per site (non-drought control and drought experiment), 5 D. magna neonates $(<24 \mathrm{~h}$ old) were placed into each of 4 replicate $50 \mathrm{~mL}$ beakers that were filled to approximately one third of the volume with sediment and $30 \mathrm{~mL}$ artificial LR water. Artificial LR water, without any sediment, was used as a toxicity test control. Daphnids were only transferred into the test beakers containing sediment after $24 \mathrm{~h}$ to allow suspended sediments to settle. Tests were conducted under static conditions at $19 \pm 1^{\circ} \mathrm{C}$ with a $16: 8$-h

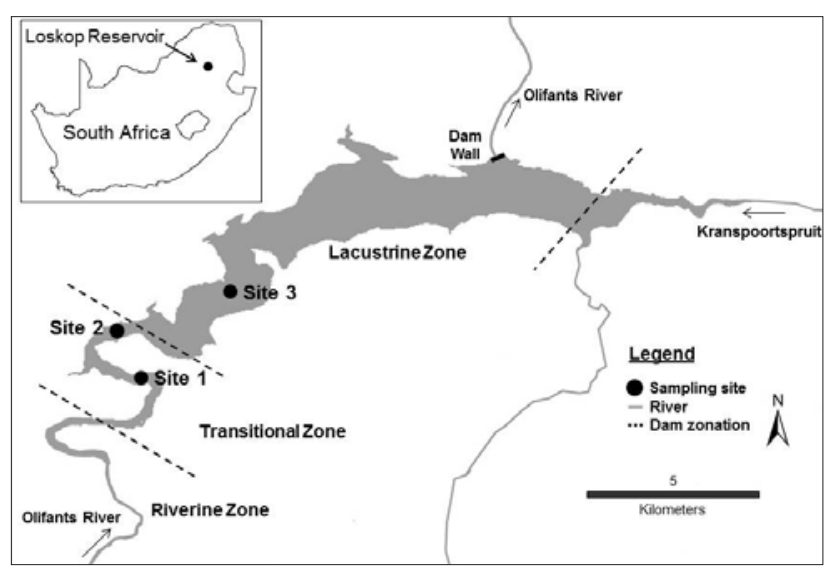

Figure 1

Map showing the location of 3 study sites at Loskop Reservoir on the Olifants River, South Africa

light:dark photoperiod for $48 \mathrm{~h}$. Daphnia were not fed during the exposure period, and the number of surviving individuals was counted at $24 \mathrm{~h}$ and $48 \mathrm{~h}$ after the test was initiated. The percentage mortality in relation to the number of organisms exposed was calculated (USEPA, 2002).

Physico-chemical parameters (electrical conductivity, dissolved oxygen, $\mathrm{pH}$ and temperature) were measured at the start and the end of the test. When the tests were concluded, the pooled water samples from all replicates per site were analysed for the same parameters as in the microcosm experiment, as well as total alkalinity as $\mathrm{CaCO}_{3}$. Results were compared to the South African Water Quality Guidelines for Aquatic Ecosystems (DWAF, 1996).

\section{RESULTS}

\section{Sediment characteristics}

The sediment moisture content (mean \pm SD; $n=5$ ) of samples from Site 1 was $28 \pm 0.3 \%$, from Site 2 was $22 \pm 5.8 \%$, and from Site 3 was $11 \pm 4.1 \%$. The physical characteristics of sediment collected from Sites 1 and 2 were similar, with higher proportions of mud and \% loss on ignition than Site 3, which was predominantly sand with low organic matter. The three metals analysed followed a spatial gradient across the reservoir, with the highest concentrations at Site 1 and decreasing towards Site 3. Total S concentrations were similar at Sites 1 and 2, but were lower at Site 3.

\section{pH and sulfate}

The $\mathrm{pH}$ values followed similar patterns at each site within respective drought and non-drought treatments (Fig. 2). During the non-drought treatment, $\mathrm{pH}$ values increased from the initial value of 6.6 to a median ranging from 7.1 to 7.4 before levelling off just below a value of 7.0 at all sites. Contrasting results were observed in the drought treatment, where there was a distinct pulse of sulfate released at all three sites. There was an initial increase in $\mathrm{pH}$ on Day 1 , followed by a decrease to minimal median values on Day 2 ranging from 6.1 to 6.4. From Day 4 onward the values increased before levelling off just above a value of 7.0. Throughout the drought treatment, $\mathrm{pH}$ values showed a spatial gradient across the reservoir, with the lowest values at Site 1 and increasing across Sites 2 and 3. 
There were distinct differences in $\mathrm{SO}_{4}^{2-}$ release between non-drought and drought treatments (Fig. 2). During the nondrought treatment values were initially very low $\left(<1.3 \mathrm{~g} / \mathrm{m}^{2}\right)$, and increased gradually over the duration of the study to a mean ranging from $1.3-3.5 \mathrm{~g} / \mathrm{m}^{2}$. Higher amounts of $\mathrm{SO}_{4}{ }^{2-}$ were released at all three sites during the drought experiment. All sites showed a similar pattern of release with a steady increase in $\mathrm{SO}_{4}^{2}$ from Day 1, reaching maximum levels between Days 7 and 11. The highest mean values ranged from 8.4 to $21.1 \mathrm{~g} / \mathrm{m}^{2}$ (Day 11). The overall amount of $\mathrm{SO}_{4}^{2-}$ released at Sites 1 and 2 was higher than at Site 3. By Day 16 these values had dropped to similar levels observed on Day 1 of the drought treatment.

\section{Nutrient dynamics}

Different patterns in $\mathrm{N}$ release were observed between the nondrought and drought treatments (Fig. 3). In the non-drought treatment, organic $\mathrm{N}$ release was highest at Site 1, but remained at consistently low lovels at all sites. There was a slight initial increase in inorganic $\mathrm{N}$, dominated by $\mathrm{NH}_{4}^{+}$, which began to decrease by the $4^{\text {th }}$ day. At this point $\mathrm{NO}_{2}{ }^{-}$and $\mathrm{NO}_{3}$ - slightly increased (Fig. 3). In contrast, dried sediments released substantially higher amounts of organic $\mathrm{N}$, which peaked between Days 7 and 11, only decreasing towards the end of the experiment. The highest organic $\mathrm{N}$ released was observed at Sites 1 and 2, while values between treatments were similar at Site 3. Ammonium steadily increased, also peaking between Days 7 and 11 at all three sites. Nitrite and nitrate were initially very low, but showed a corresponding increase as $\mathrm{NH}_{4}^{+}$began to decrease. In the drought treatment, organic $\mathrm{N}$ was positively correlated with $\mathrm{NH}_{4}^{+}$at Site 1 (Pearson's $\left.r=0.89\right)$, Site $2(r=0.87)$, and Site 3 $(r=0.84)$. In the non-drought treatment there were no significant correlations between these parameters. In both treatments the least $\mathrm{N}$ was released from Site 3 , and the highest $\mathrm{N}$ release was from Site 1, followed by Site 2 .

During the non-drought treatment, similar quantities of TP and $\mathrm{PO}_{4}^{3-}$ were released from the sediment (Fig. 4). Contrasting results were observed during the drought treatment. Total $\mathrm{P}$ released showed an initial lag phase and increased to above the non-drought treatment levels between Days 7 and 11. In both treatments the TP released was highest at Site 1 decreasing across Sites 2 and 3. In the drought treatment $\mathrm{PO}_{4}^{3-}$ release was very low following rewetting, frequently below detection limits, and below the mass observed in the non-drought treatment. Lower quantities of $\mathrm{PO}_{4}$ release were observed in the drought treatment at Sites 1 and 2, but at Site 3 there was little difference in treatment effects on $\mathrm{PO}_{4}$ release. Total $\mathrm{P}$ and organic $\mathrm{N}$ were positively correlated at Site 1 (Pearson's $r=0.61)$, Site $2(r=0.60)$, and Site 3 $(r=0.63)$ during the drought treatment.

\section{Metal dynamics}

\begin{tabular}{|l|c|c|c|}
\hline \multicolumn{4}{|c|}{ TABLE 1 } \\
\multicolumn{2}{|c|}{$\begin{array}{c}\text { Sediment characteristics (mean } \pm \text { SD) determined using } 3 \\
\text { samples collected from each site at Loskop Reservoir }\end{array}$} \\
\hline \multicolumn{1}{|c|}{ Characteristic } & Site 1 & Site 2 & Site 3 \\
\hline \% gravel & $5.8^{*}$ & $1.1 \pm 0.4$ & $0.1 \pm 0.1$ \\
\hline$\%$ sand & $79.7^{*}$ & $78.6 \pm 17.8$ & $99.9 \pm 0.2$ \\
\hline$\%$ mud & $14.5^{*}$ & $20.2 \pm 17.3$ & $0.8 \pm 0.1$ \\
\hline$\%$ loss on ignition & $15.6 \pm 1.8$ & $11.3 \pm 6.2$ & $0.7 \pm 0.1$ \\
\hline $\mathrm{Al}(\mathrm{g} / \mathrm{kg})$ & $74.9 \pm 7.6$ & $56.1 \pm 28.8$ & $7.0 \pm 0.7$ \\
\hline $\mathrm{Fe}(\mathrm{g} / \mathrm{kg})$ & $44.3 \pm 4.4$ & $32.5 \pm 13.1$ & $2.9 \pm 0.2$ \\
\hline $\mathrm{Mn}(\mathrm{g} / \mathrm{kg})$ & $1.8 \pm 0.2$ & $2.1 \pm 1.4$ & $0.1 \pm 0.0$ \\
\hline Total S $(\mathrm{g} / \mathrm{kg})$ & $2.5 \pm 0.2$ & $2.5 \pm 1.3$ & $0.2 \pm 0.0$ \\
\hline
\end{tabular}

${ }^{*}$ Only one sample analysed due to insufficient sediment for analyses

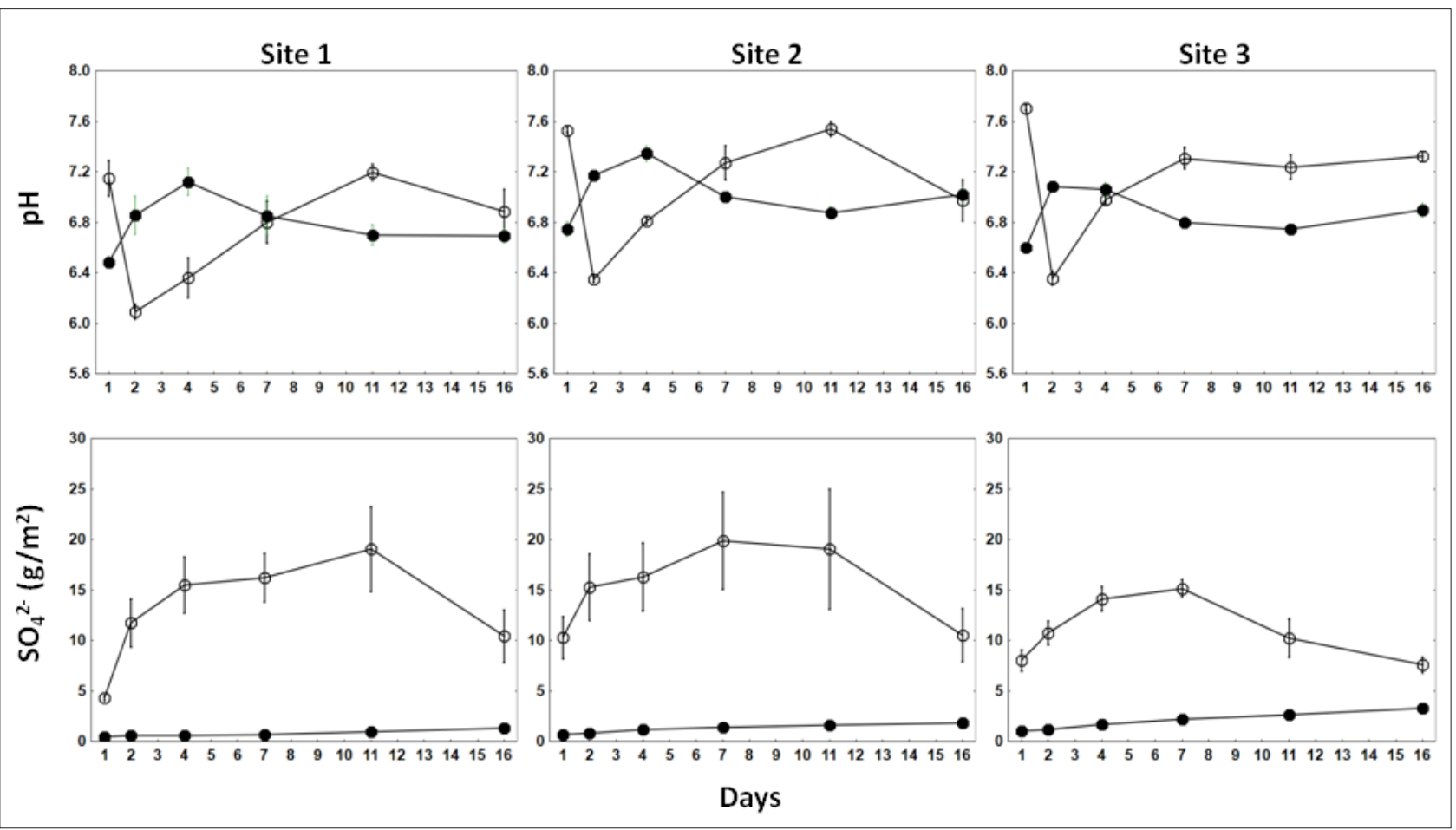

Figure 2

Median ( $\pm \min / \max ; n=5) \mathrm{pH}$ values and mean $( \pm \mathrm{SE} ; n=5)$ sulfate $\left(\mathrm{SO}_{4}{ }^{2-}\right)$ released in water where sediment was either kept wet (closed circles) or dried to simulate drought and rewet (open circles). Water samples were analysed 6 times within 16 days. 
The release of $\mathrm{Al}$ was lower in the drought treatment than the non-drought treatment at Sites 2 and 3 (Fig. 5). Al release in the non-drought treatment was highest at Sites 2 and 3. During the non-drought treatment $\mathrm{Al}$ was positively correlated with $\mathrm{Fe}$ at Site $1(r=0.97)$, Site $2(r=0.98)$, and Site $3(r=0.98)$. There were no significant correlations observed between $\mathrm{Al}$ and $\mathrm{Fe}$ in the drought treatment. During the drought treatment, $\mathrm{Al}$ concentrations were mostly below detection limits and did not increase for the duration of the study at any of the sites.

There were no distinct patterns of Fe release between sites and treatments, apart from a peak in the drought treatment on Day 7 at Site 3 (Fig. 5). In the non-drought treatment, Fe release was similar between sites and remained relatively constant. Initial Fe concentrations were very low during the drought treatment, but also increased gradually during the course of the study.

Divergent patterns in Mn release were observed between the non-drought and drought treatments. During the non-drought treatment, $\mathrm{Mn}$ release was consistently low at all sites, never exceeding $100 \mathrm{mg} / \mathrm{m}^{2}$ ). In the drought treatment, Mn increased rapidly following sediment rewetting at all sites. The $\mathrm{Mn}$ release was highest at Site 3, reaching a maximum mean of 1153.09 $\mathrm{mg} / \mathrm{m}^{2}$ on the $4^{\text {th }}$ day following rewetting. At Site 1 and Site $3 \mathrm{Mn}$ was positively correlated with $\mathrm{SO}_{4}^{2-}(r=0.62 ; r=0.64)$, and at Site $1 \mathrm{Mn}$ was negatively correlated with $\mathrm{pH}(r=-0.62)$.

\section{Toxicity test}

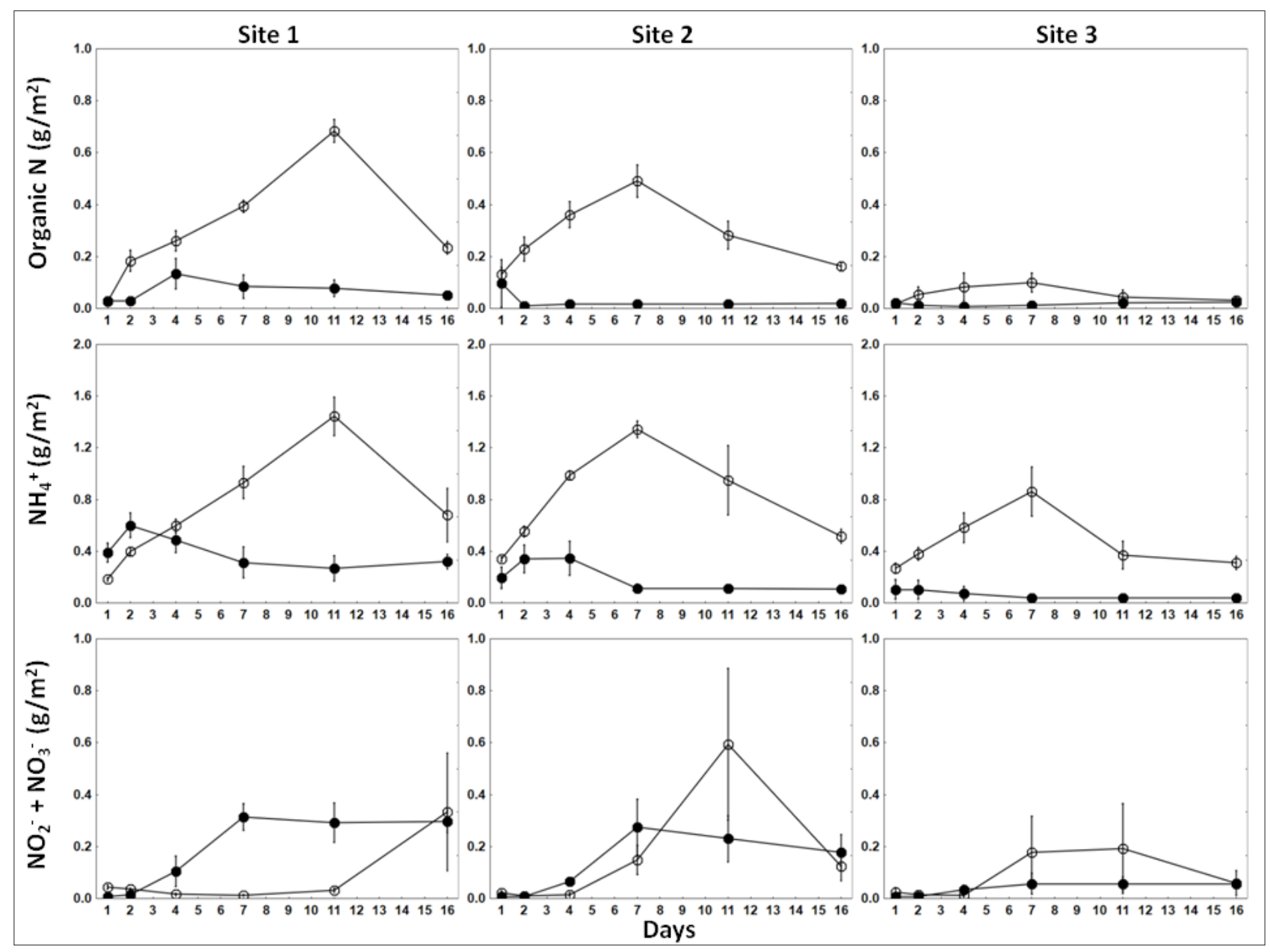

Figure 3

Mean $( \pm S E ; n=5) N$ released in water where sediment was either kept wet (closed circles) or dried to simulate drought and re-wet (open circles) Water samples were analysed 6 times within 16 days.

Physico-chemical parameters (temperature, oxygen saturation and $\mathrm{pH}$ ) measured at initiation and conclusion of the test were all within the acceptable range for Daphnia for the duration of the test (USEPA, 2002; Ghazy et al., 2011). Mortality of D. magna was not significant $(<10 \%)$ in the majority of the replicates for all sites for both the non-drought and drought treatments.

Concentrations of water quality parameters for both treatments at the conclusion of the 48-h bioassay are presented in Table 2. Total $\mathrm{N}$ and total $\mathrm{P}$ concentrations were higher in the drought treatment than the non-drought treatment, especially at Sites 1 and 2 compared to Site 3 . Ammonium made the highest contribution to the increase in total $\mathrm{N}$ at all three sites. In contrast, $\mathrm{NO}_{2}-\mathrm{NO}_{3}$ - were below detection limits at all three sites in the drought treatment, compared to low, but detectable, levels in the non-drought treatment. Orthophosphate concentrations were similar between experimental treatments with no consistent change following rewetting of dried sediments. Alkalinity as $\mathrm{CaCO}_{3}$ increased in the drought treatments at all sites, particularly Site 1 and Site 3 . At all three sites, metal concentrations were below detectable levels or at low concentrations in the nondrought treatment. Al was not detected in either treatment. Fe showed inconsistent results between treatments, as it increased during the drought treatment at Sites 1 and 2, but decreased during the drought treatment at Site 3. Mn showed a distinct increase at all three sites during the drought treatment, with values that exceeded the acute effect value (AEV) of $1.3 \mathrm{mg} / \mathrm{L}$ at 
all sites, and especially at Site 3 where the alkalinity was the lowest and the toxicity potential, as a result, the highest. The AEV is defined as the concentration above which significant toxic effects are expected for up to $5 \%$ of the species in the aquatic community (DWAF, 1996).

\section{DISCUSSION}

The reduction in $\mathrm{pH}$ observed immediately following rewetting of dried sediments suggests the potential for mild acidification to occur following sediment rewetting in LR. The reduced $\mathrm{pH}$ is consistent with the formation of acids from sulfide oxidation. The gradual increase in $\mathrm{pH}$ during the drought treatment of the microcosm study suggested buffering, which was supported by an increase in alkalinity in the drought treatment of the toxicity test. Based on these results, acidification resulting from sulfide oxidation would be for a limited period as the buffering capacity of the sediments appeared to prevent sustained acidification. The acidification effect could be enhanced or mitigated to an extent by the quality of the inflowing water. The low $\mathrm{pH}$ values reported near the inflow in 2009 (Oberholster et al., 2010) are, therefore, likely to have been related to the quality of inflowing water as opposed to internally generated acidification. However, during this study the $\mathrm{pH}$ values were lowest at Site 1 and increased towards Site 3. This suggests that the elements responsible for acidification following rewetting (mainly $\mathrm{SO}_{4}{ }^{2-}$ ) show a pattern of enrichment towards the inflow, which has been observed in previous studies (Dabrowski et al., 2013). The sediment samples were also more enriched with S at Sites 1 and 2 than Site 3. The area upstream of Site 1 was inaccessible during fieldwork for this study and could not be sampled. This area is a hotspot for highly-concentrated algal blooms, low-oxygen events and fish kills (Dabrowski et al., 2013), and may be more susceptible to acidification following drought than the sites evaluated in this

\begin{tabular}{|c|c|c|c|c|c|c|}
\hline \multicolumn{7}{|c|}{$\begin{array}{l}\text { TABLE } 2 \\
\text { Various parameters measured in pooled water where sediment was either kept wet (non-drought) or dried and then rewet } \\
\text { (drought). Samples were collected at conclusion of the } 48 \mathrm{~h} \text { Daphnia toxicity test. Values in bold exceed AEV (DWAF, 1996). }\end{array}$} \\
\hline \multirow[t]{2}{*}{ Parameter (mg/L) } & \multicolumn{2}{|c|}{ Site 1} & \multicolumn{2}{|c|}{ Site 2} & \multicolumn{2}{|c|}{ Site 3} \\
\hline & Non-drought & Drought & Non-drought & Drought & Non-drought & Drought \\
\hline Total N & 6.1 & 35.0 & 8.8 & 35.0 & 2.2 & 22 \\
\hline $\mathrm{NO}_{2}^{-}+\mathrm{NO}_{3}^{-}$ & 3.4 & $<0.1$ & 3.5 & $<0.1$ & 1.0 & $<0.1$ \\
\hline $\mathrm{NH}^{+}$ & 1.7 & 22.0 & 5.2 & 20.0 & 0.49 & 14.0 \\
\hline Total P & 0.19 & 0.46 & 0.18 & 0.73 & 0.11 & 0.15 \\
\hline $\mathrm{PO}_{4}^{3-}$ & 0.08 & 0.06 & 0.08 & 0.08 & 0.06 & 0.09 \\
\hline Alkalinity as $\mathrm{CaCO}_{3}$ & 53.0 & 125.0 & 99.0 & 114.0 & 8.2 & 41.0 \\
\hline $\mathrm{Al}$ & $<0.01$ & $<0.01$ & $<0.01$ & $<0.01$ & $<0.01$ & $<0.01$ \\
\hline $\mathrm{Fe}$ & $<0.01$ & 0.28 & $<0.01$ & 0.15 & 0.02 & $<0.01$ \\
\hline $\mathrm{Mn}$ & $<0.01$ & 12.00 & $<0.01$ & 9.10 & 0.49 & 20.00 \\
\hline
\end{tabular}

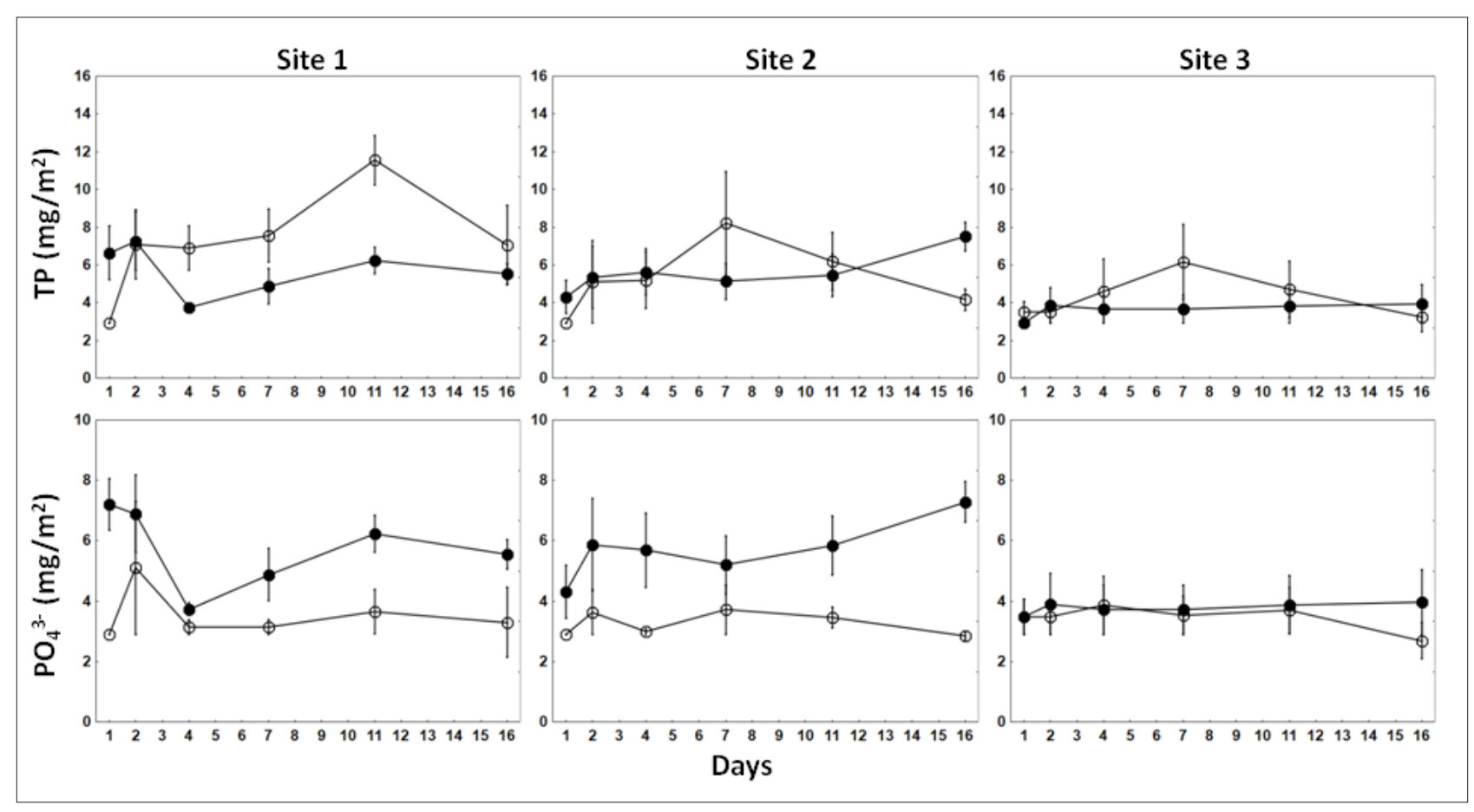

Figure 4

Mean ( $\pm S E ; n=5)$ P released in water where sediment was either kept wet (closed circles) or dried to simulate drought and then re-wet (open circles). Water samples were analysed 6 times within a period of 16 days. 
study. Elevated $\mathrm{SO}_{4}{ }^{2-}$ concentrations following rewetting have been observed in similar studies, and are the result of oxidation of insoluble $\mathrm{FeS}_{\mathrm{x}}$ from the sediment during desiccation (Lucassen et al., 2005; Fernandez-Alaez and Fernadez-Alaez, 2010). The decrease in $\mathrm{pH}$ values follows the oxidation of $\mathrm{SO}_{4}^{2-}$, which is mobilised as $\mathrm{H}_{2} \mathrm{SO}_{4}$ during rewetting (Eimers et al., 2004). The decrease in $\mathrm{SO}_{4}^{2-}$ following Day 11 may have indicated the onset of sulfate reduction, although this is not consistent with the observed increase in $\mathrm{NO}_{2}^{-}+\mathrm{NO}_{3}^{-}$at around the same time, which suggested the onset of nitrification under aerobic conditions.

The release of nutrients following rewetting of dried soils is known as the Birch effect (Birch, 1960). A similar release of nutrients following rewetting of aquatic sediments has been reported, but the results are not always consistent. Factors that influence nutrient release include the inundation history of the sediments (Wilson and Baldwin, 2008), frequency of desiccation (Song et al., 2007), sediment Fe and P content (Lucassen et al., 2005), duration of desiccation and the microbial consortium present (Baldwin \& Mitchell, 2000).

Higher concentrations of organic $\mathrm{N}$ were released from dried sediments at Site 1 and Site 2, which is consistent with the higher carbon content of the sediments at those sites. The rapid release of $\mathrm{NH}_{4}^{+}$following rewetting of dried sediments has been reported in similar studies conducted under aerobic conditions (Birch, 1960; Qiu \& McComb, 1996; Baldwin et al.,
2006; Wilson and Baldwin, 2008). In both the drought and non-drought treatments, the release of $\mathrm{NH}_{4}^{+}$stimulated nitrification resulting in an increase in $\mathrm{NO}_{2}{ }^{-}+\mathrm{NO}_{3}{ }^{-}$concentrations. Elevated $\mathrm{NH}_{4}^{+}$levels during the drought treatment could not be attributed to reduction of $\mathrm{NO}_{3}{ }^{-}$to $\mathrm{NH}_{3}$ because, firstly, the experiment was conducted under aerated conditions, secondly, $\mathrm{NO}_{2}^{-}+\mathrm{NO}_{3}^{-}$concentrations were very low at commencement of the study and. finally, the desiccation of sediments is known to kill a large proportion of microbial biomass responsible for ammonification (Qiu and McComb, 1996). The source of $\mathrm{NH}_{4}^{+}$ release may be attributed to drying-induced microbial cell lysis (Birch, 1960; Qiu and McComb, 1996). This quite likely occurred during the drought treatment as sediments were deliberately selected from depths infrequently exposed to desiccation where bacteria are not selected to withstand frequent or extended dry periods (Wilson and Baldwin, 2008). Nitrification was the dominant reaction in both non-drought and drought treatments. However, a lag period (adaptation phase) in the drought treatment indicated the reactivation of nitrifying bacteria which has been characterised by a delay in the increase of $\mathrm{NO}_{3}$ - following rewetting (Qiu and McComb, 1996).

The increase in total $\mathrm{P}$ following a lag period when sediments were rewet was consistent with previous studies, along with the positive correlation between organic $\mathrm{N}$ and total $\mathrm{P}$ (Wilson and Baldwin, 2008). The elevated values in the drought treatment were within the range of total $\mathrm{P}$ values reported in LR

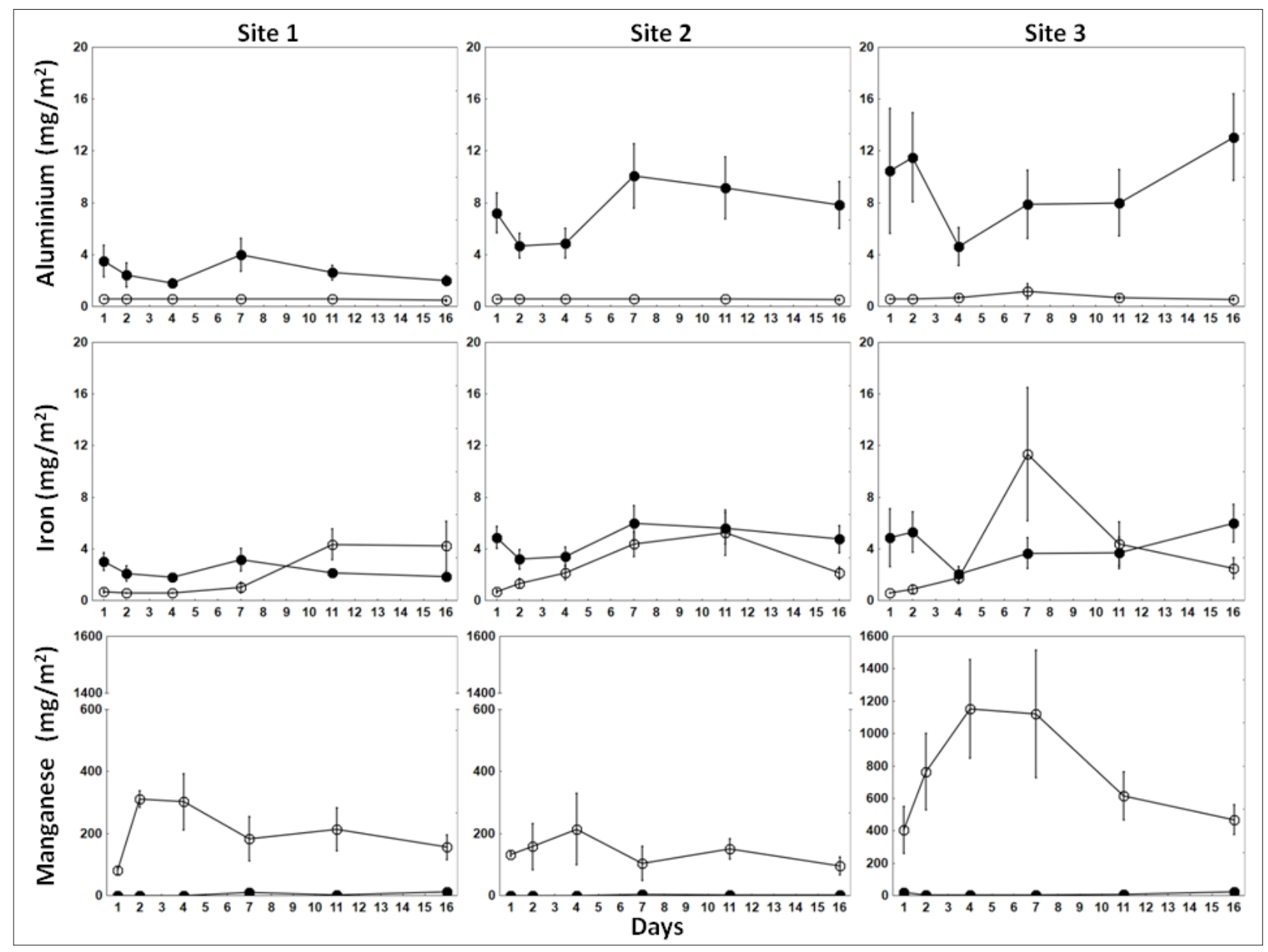

Figure 5

Mean ( $\pm S E ; n=5) A l$, Fe and Mn in water where sediment was either kept wet (closed circles) or dried to simulate drought and then re-wet (open circles). Water samples were analysed 6 times within a period of 16 days. Note scale breaks in Sites 1 and $2 \mathrm{Mn}$ concentrations. 
following the drought (Dabrowski et al., 2013). The decreasing pattern in total $P$ release from Site 1 to Site 3 could be related to a similar pattern in sediment organic matter (\% loss on ignition). Despite a slight increase on Day 2, concentrations of $\mathrm{PO}_{4}{ }^{3}$ were lowest following the simulated drought, which has also been observed in previous studies (Wilson and Baldwin, 2008; Palomo et al., 2013). This may be attributed to complexes formed between $\mathrm{PO}_{4}^{3-}$ and $\mathrm{Fe}\left(\mathrm{FePO}_{4}\right)$ and $\mathrm{Al}\left(\mathrm{AlPO}_{4}\right.$; Jiang et al., 2006). The oxidation of insoluble $\mathrm{FeS}_{\mathrm{x}}$ mobilises $\mathrm{SO}_{4}^{2-}$ and results in precipitation of $\mathrm{Fe}$ as $\mathrm{Fe}(\mathrm{III})$ hydroxides and $\mathrm{FePO}_{4}$. Therefore, sediments with significant deposits of $\mathrm{FeS}_{\mathrm{x}}$ have a greater capacity to bind $\mathrm{PO}_{4}^{3-}$ following desiccation (Lucassen et al., 2005; Schönbrunner et al., 2012). Given the combined mining-related impacts of increasing $\mathrm{SO}_{4}^{2-}$ and elevated Fe concentrations in LR (De Villiers and Mkwelo, 2009; Oberholster et al., 2010; Dabrowski et al., 2013), the sediments are likely to contain enriched deposits of both elements, resulting in an increased $\mathrm{P}$ adsorption capacity under aerobic conditions. If anaerobic conditions develop in the sediment following inundation, however, reduction of Fe compounds results in the re-mobilization of $\mathrm{PO}_{4}^{3-}$ (Havens, 1997). This is accelerated by $\mathrm{SO}_{4}^{2-}$ reduction, which can reduce $\mathrm{Fe}$ (III) from $\mathrm{FePO}_{4}$, resulting in the formation of $\mathrm{FeS}_{\mathrm{x}}$ and mobilisation of $\mathrm{PO}_{4}^{3-}$ (Lucassen et al., 2005). This is an important, and as yet unexplored, aspect of the dynamics of $\mathrm{P}$ release following sediment desiccation in LR, as it has a monomictic pattern of summer stratification during which oxygen is depleted in the underlying water layers (Dabrowski et al., 2013). Elevated inorganic $\mathrm{N}$ and reduced $\mathrm{PO}_{4}{ }^{3-}$ observed in this study would produce high ratios of dissolved inorganic $\mathrm{N}$ to dissolved inorganic $\mathrm{P}$ in the drought treatment. This situation is not usually associated with eutrophication under the conventional assumption of P-limited conditions. It is also not consistent with the reported increases in total and dissolved $\mathrm{P}$ that followed refilling of the reservoir (Dabrowski et al., 2013). However, factors such as the limited timeframe, lack of anaerobic phase, and unknown quality of inflowing water constrain direct comparisons between the results of this study and observed water quality in LR.

The initial decrease in Fe following rewetting, followed by a lag period and then increasing concentrations, is consistent with previous studies (Lucassen et al., 2002; Lucassen et al., 2005). The initial reduction has been attributed to the formation of insoluble Fe (hydr)oxides. Following a lag period, Fe concentrations increased from around Day 7 as Fe(III) (hydr)oxides were reduced to mobile $\mathrm{Fe}(\mathrm{II})$. Al concentrations were sustained below detection limits throughout the drought treatment at all sites, implying the formation of insoluble (hydr)oxides. As Al is insensitive to fluctuations in redox potential, the $\mathrm{Al}$ (hydr) oxides remained immobile in contrast to redox-sensitive Fe. The solubility and speciation of $\mathrm{Al}$ is most influenced by $\mathrm{pH}$, with hydroxides dominating between a $\mathrm{pH}$ of 5 and 9 (Gensemer and Playle, 1999). The $\mathrm{pH}$ values remained within this range for the duration of the study and therefore $\mathrm{Al}$ remained insoluble.

The chemical behaviour of $\mathrm{Mn}$ is similar to $\mathrm{Fe}$, and is sensitive to changes in redox potential, dissolved oxygen, $\mathrm{pH}$, hardness and organic matter (DWAF, 1996). Fe and Mn were not significantly correlated at any site during the drought treatment, and the aerobic conditions maintained during the study eliminated dissolved oxygen or redox potential from having an influence on results. Elevated concentrations of Mn were observed in the drought treatments of both the microcosm and toxicity test studies. Although Mn concentrations substantially exceeded the AEV of $1.3 \mathrm{mg} / \mathrm{L}$ in the drought treatment of both studies, the lack of D. magna mortalities indicated that it was not in a toxic or bio-available form. The absence of a lag phase in the release of Mn suggests a drying-related process as opposed to a microbially-mediated one. High concentrations may have arisen from the formation of Mn salts, which show a corresponding increase to nitrate, sulfate and chloride $(\mathrm{Cl})$ and are fairly soluble in water (DWAF, 1996). The positive correlations between $\mathrm{Mn}$ and $\mathrm{SO}_{4}^{2-}$ at Sites 1 and 3 support this conclusion. During the drought treatment, the $\mathrm{pH}$ at Site 1 had the lowest values which were negatively correlated with Mn concentrations. Manganese salts are stable in alkaline solution, but disproportionate in neutral and acidic solutions (Greenwood and Earnshaw, 1998). There were no significant correlations between $\mathrm{Mn}$ and $\mathrm{NO}_{3}$ at any sites, and $\mathrm{Cl}$ was not measured in this study. Mn may have been in the colloidal phase which is still filterable through a $0.45 \mu \mathrm{m}$ filter but has limited bioavailability. A further explanation may be related to the sediment mineralogy which is known to alter during desiccation, with changes in the surface area and available binding sites (Baldwin and Mitchell, 2000). The sediment at Site 3 (which had the highest $\mathrm{Mn}$ release) was distinctive in having very high sand and low carbon content.

While increased nutrients do not exert toxic effects on $D$. magna, zooplankton may be indirectly affected by nutrientstimulated growth of phytoplankton that are inedible or produce toxins. Knowledge of the underlying processes is still incomplete, but these results showed that sediment desiccation had important effects on metal and nutrient dynamics, but resulted in no acute toxic effects to $D$. magna. Toxic effects can, however, not be ruled out in longer term exposures of Daphnia.

Site-specific knowledge of the dynamics of pollutant retention and release from reservoir sediments is rarely investigated or incorporated into reservoir and catchment management plans. However, the results of this study show that drying-induced changes in biogeochemical cycles of reservoir sediments have the potential to negatively influence water quality and aquatic ecosystem health, with implications for all users. This lack of knowledge limits our ability to set effective water quality guidelines, predict the impacts of drought on our stored water resources, and have a more comprehensive understanding of water quality in our stored water resources. For instance, this study confirmed one of the drying-induced risks posed by increasing $\mathrm{SO}_{4}^{2-i n p u t s}$ to LR. Although the acidification effect observed in this study was mild, this could be exacerbated by continued and increasing inputs of $\mathrm{SO}_{4}{ }^{2-}$ originating from acid mine drainage from the catchment. The $\mathrm{SO}_{4}^{2-}$ concentrations at LR show an increasing trend (Dabrowski et al., 2013) and have increased more than 7 -fold since the 1970s (De Villiers and Mkwelo, 2009). Although treated mine-water may have a low metal content due to precipitation by liming agents, the $\mathrm{SO}_{4}{ }_{4}^{2-}$ content is rarely addressed and is frequently very high. Therefore, treatment of mine-water should include the reduction of $\mathrm{SO}_{4}{ }^{2-}$ levels so as to reduce the risk of acidification along with increased anaerobic $\mathrm{H}_{2} \mathrm{~S}$ production in lake sediments. Future studies of this nature must include an anaerobic phase in order to account for periods of lake stratification.

\section{ACKNOWLEDGEMENTS}

This research was funded by the Council for Scientific and Industrial Research Parliamentary Grant ECWH025.

\section{REFERENCES}

APHA (American Public Health Association) (2005) Standard Methods for the Examination of Water and Wastewater ( $21^{\text {st }}$ edn $)$. American Public Health Association (APHA), American Water Works 
Association (AWWA), and Water Pollution Control Federation (WPCF), Washington DC, USA.

BALDWIN DS and MITCHELL AM (2000) The effects of drying and re-flooding on the sediment and soil nutrient dynamics of lowland river-floodplain systems: A synthesis. Regul. Rivers: Res. Manage. 16 457-467. https:/doi.org/10.1002/10991646(200009/10)16:5<457::AID-RRR597>3.0.CO;2-B

BALDWIN DS, CROOME R, MATEEV V, MITCHELL A, OLIVER R, SHERMAN B and WILLIAMS J (2006) Cyanobacterial (blue-green algal) blooms in Lake Hume. A report to Lake Hume blue-green algal task force. Murray-Darling Freshwater Research Centre (MDFRC), Albury, Australia.

BALDWIN DS and FRASER M (2009) Rehabilitation options for inland waterways impacted by sulfidic sediments - a synthesis. J. Environ. Manage. 91 311-319. https:/doi.org/10.1016/j.jenvman.2009.09.006

BIRCH HF (1960) Nitrification in soils after different periods of dryness. Plant Soil 12 81-96. https:/doi.org/10.1007/BF01377763

DABROWSKI JM and DE KLERK LP (2013) An assessment of the impact of different land use activities on water quality in the upper Olifants River catchment. Water SA 39 231-244. https:/doi. org/10.4314/wsa.v39i2.6

DABROWSKI J, OBERHOLSTER PJ, DABROWSKI JM, LE BRASSEUR J and GIESKES J (2013) Chemical characteristics and limnology of Loskop Dam on the Olifants River (South Africa), in light of recent fish and crocodile mortalities. Water SA 39 675-686. https:/doi. org/10.4314/wsa.v39i5.12

DABROWSKI J, HALL G, LUBCKER N, OBERHOLSTER PJ, PHILLIPS DL and WOODBORNE S (2014a) Piscivory does not cause pansteatitis (yellow fat disease) in Oreochromis mossambicus from an African subtropical reservoir. Freshwater Biol. 59 1484-1496. https:/doi.org/10.1111/fwb.12360

DABROWSKI J, OBERHOLSTER PJ and DABROWSKI JM (2014b) Water quality of Flag Boshielo Dam, Olifants River, South Africa: historical trends and the impact of drought. Water SA 40 345-357. https:/doi.org/10.4314/wsa.v40i2.17

DE VILLIERS S and MKWELO ST (2009) Has monitoring failed the Olifants River, Mpumalanga? Water SA 35 (5) 671-676. https:/doi. org/10.4314/wsa.v35i5.49193

DWAF (Department of Water Affairs and Forestry, South Africa) (1996) South African Water Quality Guidelines. Vol. 7: Aquatic Ecosystems. Department of Water Affairs and Forestry, Pretoria.

EIMERS MC, DILLON PJ and WATMOUGH SA (2004) Long-term (18-year) changes in sulfate concentrations in two Ontario headwater lakes and their inflows in response to decreasing deposition and climate variations. Hydrol. Processes 18 2017-2630. https:/doi. org/10.1002/hyp. 5570

ENGELBRECHT FA, MCGREGOR JL and ENGELBRECHT CJ (2009) Dynamics of the Conformal-Cubic Atmospheric Model projected climate-change signal over southern Africa. Int. J. Climatol. 29 1013-1033. https:/doi.org/10.1002/joc.1742

ENGELBRECHT FA, ADEGOKE J, BOPAPE M-J, NAIDOO M, GARLAND R, THATCHER M, MCGREGOR J, KATZFEY J, WERNER M, ICHOKU C and GATEBE C (2015) Projections of rapidly rising surface temperatures over Africa under low mitigation. Environ. Res. Letters 10 085004. https:/doi. org/10.1088/1748-9326/10/8/085004

FERNANDEZ-ALAEZ M and FERNANDEZ-ALAEZ C (2010) Effects of the intense summer desiccation and the autumn filling on the water chemistry in some Mediterranean pools. Limnetica 29 59-74.

GENSEMER RW and PLAYLE RC (1999) The bioavailability and toxicity of aluminium in aquatic environments. Crit. Rev. Environ. Sci. Technol. 29 315-450. https:/doi.org/10.1080/10643389991259245

GREENWOOD NN and EARNSHAW A (1998) Manganese, technetium and rhenium. In: Chemistry of the Elements ( $2^{\text {nd }}$ edn). Butterworth Heinemann, Oxford, UK.

HAVENS KE (1997) Water levels and total phosphorus in Lake Okeechobee. Lake Reserve. Manage. 13 16-25. https:/doi. org/10.1080/07438149709354292

HUCHZERMEYER KDA, GOVENDER D, PIENAAR D and DEACON AR (2011) Steatitis in wild sharptooth catfish, Clarius gariepinus (Burchell), in the Olifants and lower Letaba Rivers in the Kruger National Park, South Africa. J. Fish. Dis. 4 489-498.
JIANG X, JIN X, YAO Y, LI L and WU F (2006) Effects of oxygen on the release and distribution of phosphorus in the sediments under the light condition. Environ. Pollut. 141 482-487. https:/doi. org/10.1016/j.envpol.2005.08.071

KEITEL J, ZAK D and HUPFER M (2016). Water level fluctuations in a tropical reservoir: the impact of sediment drying, aquatic macrophyte dieback, and oxygen availability on phosphorus mobilization. Environ. Sci. Pollut. Res. 23 6883-6894. https:/doi.org/10.1007/ s11356-015-5915-3

KRUGER AC (2006) Observed trends in daily precipitation indices in South Africa: 1910-2004. Int. J. Climatol. 26 2275-2285. https:/doi. org/10.1002/joc. 1368

LAKE S (2011) Drought and Aquatic Ecosystems: Effects and Responses. Wiley Blackwell, West Sussex, UK. https:/doi. org/10.1002/9781444341812

LUCASSEN ECHET, SMOLDERS AJP and ROELOFS JGM (2002) Potential sensitivity of mires to drought, acidification and mobilisation of heavy metals: the sediment $\mathrm{S} /(\mathrm{Ca}+\mathrm{Mg})$ ratio as diagnostic tool. Environ. Pollut. 120 635-646. https:/doi.org/10.1016/ S0269-7491(02)00190-2

LUCASSEN ECHET, SMOLDERS AJP and ROELOFS JGM (2005) Effects of temporary desiccation on the mobility of phosphorus and metals in sulfur-rich fens: differential responses of sediments and consequences for water table management. Wetland Ecol. Manage. 13 135-148. https:/doi.org/10.1007/s11273-004-0314-4

NASELLI-FLORES L (2003) Man-made lakes in Mediterranean semi-arid climate: the strange case of Dr Deep Lake and Mr Shallow Lake. Hydrobiologia 506-509 13-21. https:/doi. org/10.1023/B:HYDR.0000008550.34409.06

NEAGARI Y, ARII S, UDAGAWA M, ONUMA M, ODAYA Y, KAWASAKI T, TENPAKU M, HAYAMA H, HARADA K-I, MIZUKAMI M and MURATA K (2011) Steatitis in egrets and herons from Japan. J. Wildl. Dis. 47 49-55. https:/doi. org/10.7589/0090-3558-47.1.49

NICHOLS DK, CAMPBELL VL and MONTALI RJ (1986) Pansteatitis in great blue herons. J. Am. Vet. Med. Assoc. 189 1110-1112.

OBERHOLSTER PJ, MYBURGH JG, ASHTON PJ and BOTHA A-M (2010) Responses of phytoplankton upon exposure to a mixture of acid mine drainage and high levels of nutrient pollution in Lake Loskop, South Africa. Ecotoxicol. Environ. Saf. 73 326-335. https:/doi. org/10.1016/j.ecoenv.2009.08.011

OBERHOLSTER PJ and BOTHA A-M. (2011) Dynamics of phytoplankton and phytobenthos in Lake Loskop (South Africa) and downstream irrigation canals. Fundam. Appl. Limnol. 179 169-178. https:/ doi.org/10.1127/1863-9135/2011/0179-0169

OBERHOLSTER PJ, MYBURGH JG, ASHTON PJ, COETZEE JJ and BOTHA A-M (2012) Bioaccumulation of aluminium and iron in the food chain of Lake Loskop, South Africa. Ecotoxicol. Environ. Saf. 75 134-141. https:/doi.org/10.1016/j.ecoenv.2011.08.018

PALOMO L, MEILE C and JOYE SB (2013) Drought impacts on biogeochemistry and microbial processes in salt marsh sediments: a flow-through reactor approach. Biogeochemistry 112 389-407. https:/ doi.org/10.1007/s10533-012-9734-Z

QIU S and MCCOMB AJ (1994) Effects of oxygen concentration on phosphorus release from reflooded air-dried wetland sediments. Aust. J. Mar. Freshwater Res. 45 1319-1328. https:/doi.org/10.1071/ MF9941319

QIU S and MCCOMB AJ (1995) Planktonic and microbial contributions to phosphorus release from fresh and air-dried sediments. Mar. Freshwater Res. 46 1039-1045. https:/doi.org/10.1071/mf9951039

QIU S and MCCOMB AJ (1996) Drying-induced stimulation of ammonium release and nitrification in reflooded lake sediment. Mar. Freshwater Res. 47 531-536. https:/doi.org/10.1071/mf9960531

REES GN, WATSON GO, BALDWIN DS and MITCHELL AM (2006) Variability in sediment microbial communities in a semipermanent stream: impact of drought. J. N. Am. Benthol. Soc. 25 370-378. https:/ doi.org/10.1899/0887-3593(2006)25[370:VISMCI]2.0.CO;2

SCHONBRUNNER IM, PREINER S and HEIN T (2012) Impact of drying and re-flooding of sediment on phosphorus dynamics of river-floodplain systems. Sci. Total Environ. 432 329-337. https:/doi. org/10.1016/j.scitotenv.2012.06.025 
SONG K-Y, ZOH K-D and KANG H (2007) Release of phosphate in a wetland by changes in hydrological regime. Sci. Total. Environ. $\mathbf{3 8 0}$ 13-18. https:/doi.org/10.1016/j.scitotenv.2006.11.035

SOUCEK DJ, CHERRY DS and TRENT GC (2000) Relative acute toxicity of acid mine water column and sediment to Daphnia magna in the Puckett's Creek Watershed, Virginia, USA. Arch. Environ. Contam. Toxicol. 38 305-310. https:/doi.org/10.1007/s002449910040

USEPA (United States Environmental Protection Agency) (2002) ShortTerm Methods for Estimating the Chronic Toxicity of Effluents and
Receiving Waters to Freshwater Organisms. ( $4^{\text {th }}$ edn). Report no. EPAEPA-821-R-02-013. USA. United States Environmental Protection Agency, Washington DC. 335 pp.

WILSON JS and BALDWIN DS (2008) Exploring the 'Birch effect' in reservoir sediments: influence of inundation history on aerobic nutrient release. Chem. Ecol. 24 379-386. https:/doi. org/10.1080/02757540802497582 